\title{
Peranan Penerimaan Negara Bukan Pajak dalam Pendapatan dan Belanja Negara
}

\author{
Dina Rosdiana Rusdi \\ Magister Ilmu Hukum, Universitas Indonesia \\ dinarosdiana@gmail.com
}

\begin{abstract}
Abstrak. Penerimaan Negara Bukan Pajak merupakan salah satu sumber pendapatan negara. Dalam upaya pencapaian tujuan nasional sebagaimana dalam Undang-undang Dasar 1945, pemerintah menyelenggarakan kegiatan pemerintahan dan pembangunan nasional. Penerimaan Negara Bukan Pajak merupakan salah satu penerimaan negara dengan kontribusi yang cukup signifikan. Bersama dengan jenis penerimaan negara lainnya, Penerimaan Negara Bukan Pajak ikut serta menopang keuangan negara. Sayangnya, informasi mengenai Penerimaan Negara Bukan Pajak masih terbilang terbatas pada data realisasi dan penjelasan pendukung pencapaian realisasi tersebut. Kondisi ini yang menyebabkan proses edukasi mengenai Penerimaan Negara Bukan Pajak kepada khalayak menjadi sedikit tersendat. Dengan begitu luasnya cakupan Penerimaan Negara Bukan Pajak, yang banyak disorot hanya sebatas skor dan proses terjadinya gol saja. Sebagai salah satu sumber pendapatan negara, Penerimaan Negara Bukan Pajak memiliki peran yang cukup penting dalam penopang kebutuhan pendanaan anggaran dalam Anggaran Pendapatan dan Belanja Negara.
\end{abstract}

Kata Kunci : Penerimaan Negara Bukan Pajak, Keuangan Negara, Anggaran Pendapatan dan Belanja Negara.

Abstract. Non-tax State Revenue is a source of state revenue. In an effort to achieve national goals as stipulated in the 1945 Constitution, the government shall carry out government activities and national development. Non-tax State Revenue is one of the state revenues with a significant contribution. Together with other types of state revenue, Non-Tax State Revenue participates in supporting state finances. Unfortunately, the information regarding Non-Tax State Revenues is still limited to the realization data and the supporting explanations for the realization. This condition causes. the education process regarding Non-Tax State Revenue to the public to be a little choked up. With such a wide coverage of Non-Tax State Revenues, what is mostly highlighted is only the score and the process of the goal. As one of the sources of state revenue, Non-Tax State Revenues have an important role in supporting budget funding needs in the State Revenue and Expenditure Budget.

Keywords: Non-Tax State Revenue, State Finance, and State Budget.

\section{PENDAHULUAN}

Penyelenggaraan pemerintahan merupakan wujud eksistensi keberadaan suatu negara. Salah bentuk penyelenggaraan yaitu berupa pelayanan terhadap masyarakat yang merupakan tugas pemerintah untuk menjamin masyarakat dalam rangka mendapatkan penghidupan yang lebih baik. Keberadaan payung hukum merupakan penjamin bagi terwujudnya tujuan yang ingin dicapai yaitu penyelenggaraan pemerintahan berjalan dengan baik sementara masyarakat dapat mengakses segala bentuk pelayanan tersebut dalam rangka memenuhi hak-hak sebagai warga negara dalam kehidupan berbangsa dan bernegara sebagaimana yang tertuang di dalam konstitusi negara Indonesia.

Negara Kesatuan Republik Indonesia menyelenggarakan pemerintahan negara dan pembangunan nasional untuk mencapai masyarakat adil, makmur dan merata berdasarkan Pancasila dan Undang-Undang Dasar Negara Republik Indonesia Tahun 1945. Dalam rangka penyelenggaraan tujuan pemerintahan, maka pemerintah menempuh langkah dengan melaksanakan pembangunan 
disemua sektor. Dengan adanya program pembangunan ini pemerintah akan banyak membutuhkan dana untuk pelaksanannya. Dalam hal ini, untuk mempercepat proses pembangunan indonesia sangat memerlukan dana yang cukup besar untuk membangun perekonomian yang merata dan sejahtera bagi rakyatnya. Negara Kesatuan Republik Indonesia dibagi atas daerah-daerah provinsi dan daerah provinsi terdiri atas daerah-daerah kabupaten atau kota. Tiap-tiap daerah tersebut mempunyai hak dan kewajiban mengatur dan mengurus sendiri urusan pemerintahannya untuk meningkatkan efisiensi dan efektivitas penyelenggaraan pemerintahan dan pelayanan kepada masyarakat.

Pelaksanaan Anggaran Pendapatan dan Belanja Negara (APBN) telah dimulai sejak awal tahun 1950-an. Bentuk APBN pada saat itu hanya merupakan suatu perhitungan sementara sebagai dasar pembuatan APBN yang sehat di tahun-tahun berikutnya. Volume APBN juga masih sangat terbatas karena kondisi perekonomian sangat lemah yang menyebabkan potensi penerimaan negara juga sangat rendah, sekitar 40 persen penerimaan negara bersumber dari hasil pungutan pajak tidak langsung dari kegiatan perdagangan luar negeri. Peran pajak langsung baru sekitar 20 persen dari penerimaan negara, karena keterbatasan kemampuan administrasi dan basis pajak.

$$
\text { Dalam Undang-Undang Dasar }
$$

Republik Indonesia Tahun 1945 hasil amandemen keempat, mengamanatkan bahwa Anggaran Pendapatan dan Belanja Negara sebagai wujud dari pengelolaan keuangan negara ditetapkan setiap tahun dengan Undang-Undang dan dilaksanakan secara terbuka dan bertanggung jawab untuk sebesar-besar kemakmuran rakyat. Dengan ditetapkannya Undang-Undang Anggaran Pendapatan dan Belanja Negara pada setiap tahun anggaran yang merupakan bagian dari sistem keuangan negara, hibah tidak termasuk dalam bagian PNBP.

$\begin{array}{ccc}\text { Dalam } & \text { rangka mendukung } \\ \text { terwujudnya good governance dalam }\end{array}$ penyelenggaraan Negara, pengelolaan keuangan Negara perlu diselenggarakan secara profesional, terbuka dan bertanggung jawab sesuai aturan pokok yang telah ditetapkan dalam Undang-Undang Dasar. Dalam pengelolaan Keuangan Negara perlu diterapkan asas- asas antara lain:

- akuntabilitas berorientasi pada hasil;

- profesionalitas;

- proporsionalitas;

- keterbukaan dalam pengelolaan keuangan Negara;

- pemeriksaan keuangan oleh badan pemeriksa yang bebas dan mandiri.

Anggaran merupakan alat akuntabilitas, manajemen, dan kebijakan ekonomi. Sebagai instrumen kebijakan ekonomi, anggaran berfungsi untuk mewujudkan pertumbuhan dan stabilitas perekonomian serta pemerataan pendapatan dalam rangka mencapai tujuan bernegara. Anggaran sektor publik merupakan instrumen akuntabilitas atas pengelolaan dana publik dan pelaksanaan program-program yang dibiayai dari uang publik. Penganggaran sektor publik terkait dalam proses penentuan jumlah alokasi dana untuk tiap-tiap program dan aktivitas dalam satuan moneter. Anggaran adalah suatu paket pertanyaan perkiraan penerimaan dan pengeluaran yang diharapkan akan terjadi dalam satu atau beberapa periode mendatang.

Dalam UU Nomor 17 Tahun 2003 disebutkan bahwa Keuangan Negara adalah semua hak dan kewajiban negara yang dapat dinilai dengan uang, serta segala sesuatu baik berupa uang maupun berupa barang yang dapat dijadikan milik negara berhubung dengan pelaksanaan hak dan kewajiban tersebut. Lebih lanjut dikatakan bahwa hak negara untuk memungut pajak, mengeluarkan dan mengedarkan uang, dan melakukan pinjaman. Kewajiban negara untuk menyelenggarakan tugas layanan umum pemerintahan negara dan membayar tagihan pajak ketiga. Pendapatan negara adalah hak pemerintah pusat yang diakui sebagai penambah nilai kekayaan bersih. Belanja negara adalah kewajiban pemerintah pusat yang diakui sebagai pengurang nilai kekayaan bersih.

Undang-Undang Nomor 17 Tahun 2003 tentang Keuangan Negara membawa dampak perubahan Penyelenggaraan kegiatan 
dan fungsi pemerintah di bidang keuangan negara mengandung berbagai macam aspek, diantaranya adalah penerimaan negara sebagai sumber pelaksanaan kegiatan belanja negara sebagaimana tertuang dalam APBN yang merupakan amanat dari Undang-Undang Dasar Negara Republik Indonesia Tahun 1945. Penerimaan negara merupakan sumber keuangan negara yang digunakan untuk membiayai pelaksanaan tugas pemerintah dalam rangka pencapaian tujuan negara. Pencapaian tujuan negara tergantung dari pendapatan negara sebagai sumber keuangan negara yang diperuntuhkan untuk membiayai pelaksanaan tugas tersebut.

Untuk mewujudkan tujuan negara tersebut diatas, negara sangat membutuhkan pembiayaan yang bersumber dari penerimaan negara. Berdasarkan Undang-Undang Nomor 17 Tahun 2003 tentang Keuangan Negara (UUKN) dan Undang-Undang Nomor 1 Tahun 2004 tentang Perbendaharaan Negara diatur bahwa Pendapatan Negara adalah semua penerimaan negara yang berasal dari penerimaan perpajakan, penerimaan negara bukan pajak (PNBP), serta penerimaan hibah dari dalam negeri dan luar negeri. Adapun yang dimaksudkan dengan Pendapatan Negara adalah hak pemerintah pusat yang diakui sebagai penambah nilai kekayaan bersih. Dari pengertian tersebut berarti bahwa pemerintah pusat mempunyai berbagai hak, salah satu hak pemerintah pusat adalah menggali sumber-sumber penerimaan bagi negara untuk membiayai berbagai belanja atau pengeluaran negara yang berkaitan dengan kegiatan penyelenggaraan pemerintahan.

Pengelolaan penerimaan negara senantiasa diupayakan lebih efektif dan efisien khususnya sumber-sumber penerimaan yang berasal dari rakyat. PNBP sebagai salah satu sumber penerimaan negara bagi negara yang merupakan lingkup dari keuangan negara, pengelolaannya diharapkan senantiasa sesuai dengan koridor hukum demi terciptanya pengelolaan yang baik. Untuk itu, segala hal yang berkaitan dengan pengelolaan penerimaan negara bukan pajak diatur dalam draft Anggaran Pendapatan dan Belanja Negara (APBN).
Dengan demikian, maka pengelolaan PNBP harus berdasarkan sistem APBN yang memuat perkiraan-perkiraan tentang jumlah penerimaan negara yang akan diterima dalam satu tahun anggaran. Sebagai salah satu sumber penerimaan negara, maka PNBP harus tercantum secara rinci dalam APBN baik itu mengenai tarif, waktu pemungutan serta perkiraan jumlah yang diterima dalam satu tahun. Adapun dalam pelaksanaannya maka mengacu pada Undang-Undang atau peraturan pemerintah terkait dengan pengelolaan PNBP.

\section{Rumusan Masalah}

Berdasarkan fakta yang telah dipaparkan di atas, penulis merasa perlu untuk melakukan penulisan artikel ilmiah dengan judul Penerimaan Negara Bukan Pajak dalam Anggaran Pendapatan dan Belanja Negara. Dengan fokus pada rumusan permasalahan:

1. Bagaimana prinsip pengenaan tarif Penerimaan Negara Bukan Pajak kepada masyarakat?

2. Bagaimana peranan Penerimaan Negara Bukan Pajak dalam memberikan kontribusi bagi Anggaran Pendapatan dan Belanja Negara?

\section{Tujuan dan Manfaat Penelitian}

1. Tujuan Penelitian

Penelitian ini bertujuan untuk mengetahui, menganalisis dan memahami prinsip pengenaan tarif PNBP kepada masyarakat serta peranan Penerimaan Negara Bukan Pajak dalam memberikan kontribusi bagi Anggaran Pendapatan dan Belanja Negara.

2. Manfaat Penelitian

Penelitian ini mempunyai manfaat teoritis dan praktis. Secara teoritis penelitian ini diharapkan memberikan kontribusi dalam perkembangan ilmu pengetahuan hukum, terutama bidang hukum keuangan publik dan ilmu pengetahuan perundangundangan. Sedangkan secara praktis, hasil penelitian ini dapat digunakan sebagai sumber kajian ilmu pengetahuan bagi masyarakat umum pada umumnya dan kepada akademisi pada khususnya. 


\section{HASIL PENELITIAN DAN PEMBAHASAN}

1. Prinsip Pengengaan Tarif PNBP

a. Kewenangan Penetapan Tarif PNBP

Presiden menguasakan pengelolaan keuangan negara kepada Menteri Keuangan selaku Pengelola Fiskal, sebagaimana diamanatkan Pasal 6 ayat (2) Undang-undang (UU) Nomor 17 tahun 2003 tentang Keuangan Negara. Salah satu tugas Menteri Keuangan sebagai Pengelola Fiskal adalah mengevaluasi, menyusun, dan/atau menetapkan jenis dan tarif PNBP pada Instansi Pengelola PNBP berdasarkan usulan dari Instansi Pengelola PNBP. Hal ini diatur dalam Pasal 15 huruf b UU Nomor 9 tahun 2018. Instansi Pengelola PNBP terdiri atas Kementerian/ Lembaga dan Kementerian yang menjalankan fungsi sebagai Bendahara Umum Negara. Di lain pihak, berdasarkan ketentuan dalam Pasal 17 ayat (2) UU Nomor 9 tahun 2018, dalam mengelola PNBP yang menjadi kewenangannya, Pimpinan Instansi Pengelola PNBP, antara lain bertugas untuk menyusun dan menyampaikan usulan jenis dan tarif PNBP.

\section{b. Fungsi Pemungutan PNBP}

Pendapatan Negara Bukan Pajak (PNBP) timbul sebagai konsekuensi dari pelaksanaan tugas dan fungsi Pemerintah dalam pelayanan, pengaturan, pelindungan masyarakat, kepastian hukum, dan pengelolaan kekayaan Negara. PNBP memiliki dua fungsi utama dalam sistem pengelolaan keuangan negara: fungsi budgetary dan fungsi regulatory. Disebut memiliki fungsi budgetary karena PNBP merupakan sumber pendapatan negara terbesar setelah penerimaan perpajakan untuk mendukung pendanaan pembangunan melalui Anggaran Pendapatan dan Belanja Negara (APBN). Sementara itu, PNBP disebut memiliki fungsi regulatory atau pengaturan, karena dapat menjadi instrumen strategis dalam mengarahkan dan menetapkan regulasi dan kebijakan Pemerintah Pusat di berbagai sektor pemerintahan.

Sebagai implementasi fungsi budgetary, yang dapat dilakukan dalam meningkatkan kontribusi PNBP terhadap pendapatan Negara adalah dengan melakukan intensifikasi dan ekstensifikasi. Perwujudan intesifikasi antara lain, dengan mengoptimalkan jenis-jenis PNBP yang sudah ada dasar hukum pungutannya, namun tidak dimanfaatkan, atau meningkatkan volume pelayanan. Sementara ekstensifikasi menggali jenis-jenis PNBP untuk dapat diatur jenis dan dasar pungutan tarifnya.

Di sisi lain, pelaksanaan fungsi regulatory antara lain melalui pengaturan tarif dan penggunaan dana yang bersumber dari PNBP. Contoh fungsi regulatory melalui pengaturan tarif adalah tarif PNBP dari Dana Reboisasi kehutanan yang lebih ditujukan untuk menjaga kelestarian lingkungan dan royalty mineral dibedakan berdasarkan tingkat pengolahan/pemurnian untuk mendorong peningkatan nilai tambah dari mineral. Pengaturan ini bertujuan memberikan kepastian hukum dan mendorong peningkatan kualitas pelayanan kepada masyarakat.

Penyediaan layanan dasar bagi masyarakat, antara lain meliputi pendidikan dasar, kesehatan, keamanan, keadilan dan pelayanan lain dalam kelompok pekerjaan umum Pemerintah didanai dari APBN. Namun demikian, keterbatasan kemampuan APBN dalam membiayai seluruh pelayanan dasar memerlukan peran serta masyarakat melalui pembayaran PNBP atas jenis pelayanan dasar, contohnya biaya pendidikan tinggi dan pelayanan kesehatan. Selain itu, terdapat layanan semidasar yang hanya dibutuhkan oleh sekelompok masyarakat tertentu, sehingga dipandang tidak adil jika penyediaan pelayanan ini juga menjadi beban pembayar pajak yang tidak memanfaatkan pelayanan tersebut. Contohnya pelayanan pembuatan paspor yang hanya diperlukan oleh orang yang akan melakukan perjalanan ke luar negeri. Atas kondisi ini dikenakan pola cost sharing, di mana masyarakat pengguna pelayanan tersebut dibebankan (sebagian) beban penyelenggaraan pelayanan.

$$
\text { Pola pembagian beban }
$$

penyelenggaraan ini kemudian mempengaruhi pendekatan dalam penetapan tarif atas jenis PNBP, yaitu: tarif yang dikenakan sama dengan biaya untuk menghasilkan barang atau pelayanan (cost recovery), tarif yang dikenakan lebih rendah dari biaya untuk 
menghasilkan barang atau pelayanan (cost minus), atau tarif yang dikenakan lebih tinggi dari biaya untuk menghasilkan barang atau pelayanan (cost plus).

Dampak pengenaan tarif terhadap masyarakat, dunia usaha, dan sosial budaya, dan/atau aspek keadilan merupakan faktorfaktor pertimbangan yang sama dalam menyusun tarif pemanfaatan sumber daya alam, pelayanan, dan hak Negara lainnya. Faktor spesifik yang menjadi pertimbangan tambahan untuk pengelolaan sumber daya alam adalah nilai manfaat, kadar, atau kualitas sumber daya alam, sedangkan untuk pelayanan adalah biaya penyelenggaraan layanan.

Aspek selanjutnya yang harus dipenuhi dalam penetapan tarif PNBP berkaitan dengan biaya penyelenggaraan dari PNBP itu sendiri. Meskipun tarif PNBP harus memperhatikan dampak pengenaannya terhadap masyarakat, bukan berarti tarif PNBP ditetapkan dengan tanpa mempertimbangkan biaya penyelenggaraannya sama sekali.

c. Objek, Jenis dan Tarif atas Jenis PNBP

Berdasarkan Pasal 3 ayat (1) UU Nomor 9 tahun 2018 tentang Penerimaan Negara Bukan Pajak, yang dinyatakan sebagai Objek PNBP adalah seluruh aktivitas, hal, dan/atau benda, yang menjadi sumber penerimaan Negara di luar perpajakan dan hibah. Lebih lanjut Pasal 3 ayat (2) mengatur bahwa Objek PNBP tersebut memiliki kriteria:
1) Pelaksanaan tugas dan fungsi pemerintah;

2) Penggunaan dana yang bersumber dari anggaran pendapatan dan belanja Negara;

3) Pengelolaan kekayaan Negara, dan/atau

4) Penetapan peraturan perundangundangan.

Sesuai dengan Pasal 4 ayat (1) Objek PNBP dibagi menjadi 6 (enam) kelompok besar:

1) Pemanfaatan Sumber Daya Alam,

2) Pelayanan,

3) Pengelolaan Kekayaan Negara

Dipisahkan,

4) Pengelolaan Barang Milik Negara,
5) Pengelolaan Dana, dan

6) Hak Negara Lainnya

Dasar hukum untuk yang mengatur tarif atas jenis PNBP berbeda untuk setiap kelompok objek PNBP. Pengaturan tersebut adalah sebagai berikut:

1. Tarif atas jenis PNBP yang berasal dari Pemanfaatan Sumber Daya Alam, diatur dalam UU, Kontrak, dan/atau Peraturan Pemerintah. Pengaturan tarif atas jenis PNBP dengan kontrak merupakan pengaturan tarif atas jenis PNBP yang berasal dari Pemanfaatan Sumber Daya Alam dan memiliki kekuatan hukum mengikat sepanjang diperintahkan oleh Undang-Undang dan/atau Peraturan Pemerintah yang mengatur mengenai jenis PNBP

2. Tarif atas jenis PNBP yang berasal dari Pelayanan dan Pengelolaan Barang Milik Negara diatur dengan Peraturan Pemerintah dan/atau Peraturan Menteri.

3. Tarif atas jenis PNBP yang berasal dari Pengelolaan Kekayaan Negara Dipisahkan diatur dengan UU dan/atau dalam rapat umum pemegang saham. Pengaturan tarif atas jenis PNBP dalam rapat umum pemegang saham merupakan pengaturan penetapan tarif atas jenis PNBP yang berasal dari Pengelolaan Kekayaan Negara Dipisahkan berupa dividen bagian Pemerintah pada perusahaan perseroan dan/atau perseroan terbatas lainnya

4. Tarif atas jenis PNBP yang berasal dari Pengelolaan Dana diatur dengan Peraturan Menteri.

5. Tarif atas jenis PNBP yang berasal dari Hak Negara Lainnya diatur dengan Undang-undang, Peraturan Pemerintah (PP), dan/atau Peraturan Menteri.

Penetapan tarif melalui Peraturan Perundang-undangan merupakan ketentuan yang diatur dalam Pasal 23 A Undang-undang Dasar 1945, Pajak dan Pungutan lain yang bersifatmemaksa untuk keperluan negara diatur dengan Undang-Undang. Hal ini pula yang menyebabkan setiap pelayanan Kementerian/Lembaga yang dikenakan tarif, namun belum diatur dalam suatu perundang- 
undangan, dikategorikan sebagai pungutan tanpa dasar hukum.

\section{Peranan PNBP dalam APBN \\ a. PNBP dalam APBN}

APBN merupakan wujud pengelolaan Keuangan Negara yang ditetapkan setiap tahun dengan undang-undang yang terdiri dari anggaran pendapatan, anggaran belanja, dan pembiayaan. Dalam APBN pendapatan Negara terdiri dari penerimaan pajak, penerimaan bukan pajak, dan hibah. Dengan demikian Hibah tidak termasuk dalam kelompok penerimaan bukan pajak, namun telah berdiri sendiri sebagai sumber pendapatan dalam APBN.

Penyelenggaraan kegiatan dan fungsi pemerintah di bidang keuangan negara mengandung berbagai macam aspek, diantaranya adalah penerimaan negara sebagai sumber pelaksanaan kegiatan belanja negara sebagaimana tertuang dalam APBN yang merupakan amanat dari Undang-Undang Dasar Negara Republik Indonesia Tahun 1945. Penerimaan negara merupakan sumber keuangan negara yang digunakan untuk membiayai pelaksanaan tugas pemerintah dalam rangka pencapaian tujuan negara. Pencapaian tujuan negara tergantung dari pendapatan negara sebagai sumber keuangan negara yang diperuntuhkan untuk membiayai pelaksanaan tugas tersebut.

Dalam Undang-Undang tentang APBN, PNBP dikelompokan menjadi empat kelompok besar, yaitu:

a. Penerimaan Sumber Aaya Alam (SDA). Dalam kelompok ini, kita mengenal SDA migas dan non-migas. Pendapatan SDA migas merupakan pendapatan yang diperoleh dari bagian bersih pemerintah atas kerjasama pengelolaan sektor hulu migas. Pendapatan Non-migas dikenal dengan beberapa pendapatan sektoral yang cukup populis.

b. Pendapatan bagian laba Badan Usaha Milik Negara (BUMN) Pendapatan ini merupakan imbalan kepada pemerintah pusat selaku pemegang saham BUMN (return on equity) yang dihitung berdasarkan presentase tertentu terhadap laba bersih (pay-out ratio). Dalam APBN, pendapatan ini diklasifikasikan

ke dalam kelompok perbankan dan nonperbankan.

c. PNBP lainnya, pada prinsipnya PNBP lainnya meliputi berbagai jenis pendapatan yang dipungut oleh Kementrian Negara/Lembaga atas produk layanan yang diberikan kepada masyarakat. Termasuk di dalam kelompok ini adalah pendapatan atas pengurusan SIM, STNK, penerbitan NRKB, Passport. Pungutan yang dilakukan oleh instansi pemerintah tersebut dilakukan atas dasar Peraturan Pemerintah tentang Jenis dan Tarif atas Jenis Penerimaan Negara Bukan Pajak pada Kementrian/Lembaga tertentu.

d. Pendapatan Badan Layanan Umum (BLU) yang serupa dengan PNBP lainnya, pendapatan BLU diperoleh atas produk layanan satuan kerja instansi pemerintah yang diberikan kepada masyarakat. Adapun perbedaan mendasar yakni, pendapatan yang diperoleh melalui mekanisme BLU ini dapat langsung digunakan oleh instansi yang bersangkutan. Selain itu, jenis dan tarif PNBP BLU tidak ditetapkan berdasarkan Peraturan Pemerintah melainkan ditetapkan berdasarkan Peraturan Menteri Keuangan.

PNBP merupakan salah satu sumber penerimaan negara diluar pajak dan bea cukai yang jika ditilik kontribusinya bagi penerimaan APBN, tiap tahun mengalami peningkatan signifikan. Beberapa tahun terakhir, kontribusi PNBP terhadap APBN sekitar 30\% dari Pendapatan Negara dan Hibah, sehingga mempunyai peranan penting dalam menunjang pembangunan nasional.

PNBP memiliki peranan yang besar dan penting sebagai salah satu pilar keuangan negara. Saat ini pemerintah sedang berupaya mengoptimalkan PNBP untuk menyelenggarakan kegiatan pemerintah dan pembangunan nasional. Kontribusi PNBP terhadap pendapatan negara rata-rata sebesar $30 \%$ setiap tahun. Sebagai salah satu sumber pendapatan negara, PNBP memiliki peran yang cukup penting dalam penopang kebutuhan pendanaan anggaran dalam APBN 
walaupun sangat rentan terhadap perkembangan berbagai faktor eksternal.

Peranan penting dimaksud antara lain :

1. Mengoptimalkan penerimaan yang berasal dari kekayaan Negara bagi sebesar-besarnya kemakmuran rakyat sesuai dengan isi dan semangat pada pasal 33 Undang-Undang Dasar 1945;

2. Memperkuat basis penerimaan dalam negeri;

3. Meningkatkan disiplin dan tertib anggaran, agar semua PNBP dikelola dalam sistim APBN dan harus terlebih dahulu disetorkan ke Kas Negara;

4. Meningkatkan peranan PNBP dalam APBN dengan senantiasa mempertimbangkan kewajiban Pemerintah dalam melaksanakan kegiatan pelayanan umum dan penyelenggaraan pembangunan.

PNBP dapat dikelompokkan menjadi 4 jenis PNBP yaitu PNBP Migas, PNBP Non Migas, PNBP dari Bagian Pemerintah atas Laba BUMN dan PNBP Lainnya. PNBP Migas memiliki kontribusi terbesar dalam meningkatkan realisasi PNBP, yaitu menyumbangkan rata-rata sebesar $65 \%$ terhadap total PNBP. PNBP Lainnya yang merupakan PNBP pada Kementerian/Lembaga merupakan penyumbang terbesar kedua atau rata-rata menyumbang sebesar $20 \%$ terhadap total PNBP. Sementara itu, PNBP dari Bagian Pemerintah atas Laba BUMN dan PNBP Non Migas masing-masing menyumbang rata-rata sebesar 10\% dan 5\% terhadap total PNBP.

PNBP Migas merupakan PNBP yang diperoleh dari bagian pemerintah atas usaha atau kegiatan eksplorasi Minyak Bumi dan Gas Alam setelah dikurangkan kewajiban pemerintah terkait kegiatan usaha hulu migas. Sedangkan PNBP Non Migas merupakan PNBP yang diperoleh dari usaha atau kegiatan di bidang pertambangan umum, kehutanan, perikanan dan pertambangan Panas Bumi. PNBP dari Bagian Pemerintah atas Laba BUMN merupakan PNBP yang dihasilkan dari dividen atas kepemilikan saham pemerintah pada BUMN dan perusahaan perseroan. Sedangkan PNBP Lainnya merupakan PNBP yang diperoleh dari hasil pungutan atas pelayanan masyarakat yang dilakukan Kementerian/Lembaga.

\section{b. Penyetoran PNBP}

Tidak hanya pajak sebagai penerimaan negara yang wajib disetor ke kas negara, tetapi juga semua penerimaan negara bukan pajak. Penyetoran semua penerimaan negara bukan pajak wajib dilakukan lngsung secepatnya ke kas negara. Kas negara yang dimaksud dalam Undang-Undang PNBP adalah rekening tempat penyimpanan uang negara yang dibuka dan ditetapkan oleh menteri keuangan. Rekening itu berfungsi untuk menampung seluruh penerimaan negara, pengeluaran negara dibukukan pada setiap saat daam satu tahun anggaran serta dipertanggungjawabkan dalam Anggaran Pendapatan dan Beanja Negara.

Penyetoran penerimaan negara bukan pajak ke kas negara tersebut diaksudkan agar pengelolaannya tetap dalam Sistem Anggaran Pendapatan dan Belanja Negara. Sistem Anggaran Pendapatan dan Belanja Negara adalah suatu cara untuk mengatur masuk dan keluarnya keuangan negara berdasarkan prosedur yang telah ditentukan. Sistem ini memudahkan pemerintah untuk mengetahui penggunaan penerimaan negara bukan pajak karena pada akhir tahun anggara, wajib dipertanggungjawabkan kepada Dewan Perwakilan Rakyat.

\section{c. Pertanggungjawaban PNBP dalam APBN}

Akuntansi yang digunakan dalma laporan keuangan pemerintah adalah basis kas untuk pengakuan pendapatan, belanja dan pembiayaan dan Laporan Realisasi Anggaran dan basis akrual untuk pengakuan aset, kewajiban dan ekuitas dalam neraca. Basis kas untuk Laporan Realisasi Anggaran berarti bahwa pendapatan diakui pada saat kas diterima di rekening kas umum negara atau oleh entitas pelaporan dan belanja diakui pada saat kas dikeluarkan dari rekening Kas Umum Negara atau entitas pelaporan. Basis Akrual pada Neraca berarti bahwa aset, kewajiban, dan ekuitas dana diakui dan dicatat pada saat terjadinya transaksi, atau pada saat kejadian atau kondisi lingkungan berpengaruh pada keuangan pemerintah, tanpa memperhatikan saat kas atau setara kas 
diterima atau dibayar. Kebijakan dalam pertanggungjawaban dan pelaporan PNBP adalah:

1. Pendapatan

$$
\text { Pendapatan adalah semua }
$$

penerimaan Kas Umum Negara (KUN) yang menambah ekuitas dana lancar dalam periode tahun yang bersangkutan yang menjadi hak pemerintah pusat dan tidak perlu dibayar kembali oleh pemerintah pusat.

2. Belanja

Belanja adalah semua pengeluaran kas umum negara yang mengurangi ekuitas dana lancar dalam periode tahun yang bersangkutan yang tidak akan diperoleh pembayarannya kembali oleh pemerintah pusat. Belanja diakui pada saat terjadi pengeluaran kas dari KUN.

3. Aset

Aset adalah sumber daya ekonomi yang dikuasai dan/atau dimiliki oleh Pemerintah sebagai akibat dari peristiwa masa lalu dan dari mana manfaat ekonomi dan/atau sosial dimasa depan diharapkan dapat diperoleh, baik oleh Pemerintah maupun oleh masyarakat, serta dapat diukur dalam satuan uang.

\section{KESIMPULAN}

Penerimaan Negara Bukan Pajak merupakan penerimaan negara yang dikelola dalam sistem Anggaran Pendapatan dan Belanja Negara serta harus berdasarkan atas aturan hukum baik itu Undang-Undang maupun peraturan pemerintah yang mengatur penerimaan negara bukan pajak. Penerimaan Negara Bukan Pajak memiliki dua fungsi utama dalam sistem pengelolaan keuangan negara: fungsi budgetary dan fungsi regulatory.

Penerimaan Negara Bukan Pajak memiliki peranan yang besar dan penting sebagai salah satu pilar keuangan negara, dalam hal ini sebagai salah satu penopang Anggaran Pendapatan dan Belanja Negara. Adapun Kontribusi Penerimaan Negara Bukan Pajak terhadap pendapatan negara ratarata sebesar $30 \%$ setiap tahun. Pengelolaan Penerimaan Negara Bukan Pajak harus berdasarkan sistem Anggaran Pendapatan dan
Belanja Negara yang memuat perkiraanperkiraan tentang jumlah penerimaan negara yang akan diterima dalam satu tahun anggaran. Sebagai salah satu sumber penerimaan negara, maka Penerimaan Negara Bukan Pajak harus tercantum secara rinci dalam Anggaran Pendapatan dan Belanja Negara baik itu mengenai tarif, waktu pemungutan serta perkiraan jumlah yang diterima dalam satu tahun. Dari 4 kelompok jenis Penerimaan Negara Bukan Pajak yaitu Penerimaan Negara Bukan Pajak Migas, Penerimaan Negara Bukan Pajak Non Migas, Penerimaan Negara Bukan Pajak dari Bagian Pemerintah atas Laba BUMN dan Penerimaan Negara Bukan Pajak Lainnya, Penerimaan Negara Bukan Pajak Migas memiliki kontribusi terbesar dalam meningkatkan realisasi Penerimaan Negara Bukan Pajak.

\section{DAFTAR PUSTAKA}

Agung Dinarjito, "Pengelolaan Penerimaan Negara Bukan Pajak Study Kasus Kantor Pertanahan Wilayah Provinsi Daerah Istimewa Yogyakarta”. Jurnal PKN STAN, (Vol.1,2017)

Dina, Eva Santi Silalahi, "Strategi Kebijakan Fiskal Pemerintah Indonesia Dalam Menghadapi Dampak Pendemi Covid-19”. Jurnal Ekonomi \& Ekonomi Syariah, (Vol.3, No.2, 2020)

Direktorat Penerimaan Negara Bukan PajakDirektorat Jenderal Anggaran, "Tinta Emas Penerimaan Negara Bukan Pajak dalam Anggaran Pendapatan dan Belanja Negara". Catatan Perdana Buku I, (Kementerian Keuangan Republik Indonesia 2015)

Dwi Agustine Kurniasih, "Pembaharuan Pengelolaan Penerimaan Negara Bukan Pajak". Jurnal Rechts Vinding, (Vol.5, No.2, 2016)

Dwi Ari Wibawa, Supriadi, Evi Karmilah, "Pelaksanaan Penerimaan Negara Bukan Pajak pada Kementerian/Lembaga". Modul Analisis Pelaksanaan Penerimaan Negara Bukan Pajak, (Kementerian 
Terakreditasi Peringkat 5 (No. SK: 85/M/KPT/2020)

Keuangan Republik Indonesia 2020)

Junarso, Ridwan. 2014. Hukum Administrasi Negara dan Kebijakan

Publik.Bandung:Nuansa Cendikia

Muhammad, Djafar Saidi. 2012.Penerimaan Negara Bukan Pajak. Jakarta:Rajawali Pers

Nursanti, Masdar Mas'ud, Nur Alam , "Efektivitas dan Pengelolaan Penerimaan Negara Bukan Pajak: Studi kasus pada Kantor Pertanahan Kota Makassar Tahun 2015-2018". Jurnal Ilmu Ekonomi, (Vol.2 No.4, 2019)

Puji Astuti, Robby Martaputra, Dwi Ari Wibawa "Rekomendasi Jenis dan Tarif atas Penerimaan Negara Bukan Pajak". Modul Analisis Perencanaan Penerimaan Negara Bukan Pajak, (Kementerian Keuangan Republik Indonesia 2018)

Sutedi, Andrian.2012. Hukum Keuangan Negara.Jakarta

Yuswanto, dkk.2014.Hukum Keuangan Negara.Bandar Lampung: Justice Publisher

Undang-Undang Dasar Negara Republik Indonesia Tahun 1945

Undang-Undang Nomor 9 Tahun 2018 tentang Penerimaan Negara Bukan Pajak

Undang-Undang Nomor 17 Tahun 2003 tentang Keuangan Negara

Undang-Undang Nomor 1 Tahun 2004 tentang Perbendaharaan Negara

Undang-Undang mengenai Anggaran Pendapatan dan Belanja Negara 